\title{
An Ets motif in the proximal decidual prolactin promoter is essential for basal gene expression
}

\author{
A K Brar, C A Kessler and S Handwerger \\ Division of Endocrinology, Children's Hospital Research Foundation and Department of Pediatrics, University of Cincinnati, Cincinnati, \\ Ohio 45229, USA \\ (Requests for offprints should be addressed to A K Brar, Division of Endocrinology, Children's Hospital Medical Center, 3333 Burnet Ave, Cincinnati, \\ Ohio 45229-3039, USA; Email: anoop.brar@chmcc.org)
}

\begin{abstract}
Transcriptional regulation of the prolactin gene in the decidua differs from that in the pituitary. Several lines of evidence strongly suggest this difference is due to regulation of the prolactin gene in the decidua and other extra-pituitary tissues by tissue-specific transcription factors, which activate distinct promoters to induce prolactin gene expression in extra-pituitary sites compared with the pituitary. The human decidua is a major site of extra-pituitary expression of the prolactin gene. Here we present evidence that the transcription factor Ets-1 is critical for basal expression of the decidua-type (or decidual) prolactin promoter. Overexpression of Ets-1 significantly induces decidual prolactin promoter activity in BeWo and JAR cells that express little or no endogenous Ets-1. Conversely, a dominant/negative mutant of Ets represses basal promoter activity. Although the proximal $1.5 \mathrm{~kb}$ of the decidual prolactin promoter contains six Ets motifs, only the Ets motif at $\mathrm{nt}-77 /-71$ is essential for basal gene expression. Mutation of the Ets motif at $\mathrm{nt}-77 /-71$ results in an approximately $90 \%$ decrease in promoter activity, while mutation of the other Ets motifs results in only small changes. Electrophoretic mobility shift assays demonstrate that Ets proteins in decidualized endometrial stromal cells bind this Ets motif in the decidual prolactin promoter. Ets protein expression increases up to 20 -fold upon induction of decidualization in endometrial stromal cells under conditions in which expression of the prolactin gene is also induced. These studies provide strong evidence for a critical role of the Ets transcription factor in basal expression of the decidual prolactin promoter.
\end{abstract}

Journal of Molecular Endocrinology (2002) 29, 99-112

\section{Introduction}

In humans, the prolactin gene is expressed most highly in the decidua and pituitary gland. The amino acid sequence of decidual prolactin is identical to that of human pituitary prolactin. In the decidua, prolactin mRNA contains a noncoding exon (exon 1A) that is located approximately $6 \mathrm{~kb}$ upstream of the transcription start site of the pituitary prolactin gene (DiMattia et al. 1990, Hiraoka et al. 1991). Exon 1A is also present in other non-pituitary cells that express prolactin (for example, T-lymphocytes, brain, myometrium, dermal fibroblasts and lacrimal gland), strongly suggesting that a 'decidua-type' promoter regulates expression of the prolactin gene in extra-pituitary sites (Gellersen et al. 1989, Berwaer et al. 1994). In support of this hypothesis are numerous findings that the secretion of prolactin is regulated differently in extra-pituitary tissues compared with the pituitary (Handwerger \& Brar 2001).

At present very little is known about the transcription factors that regulate cell-specific expression of the 'decidua-type' promoter. Although the 'decidua-type' promoter contains consensus response elements for pituitary-1 (Pit-1), a transcription factor that is critical in pituitary prolactin gene expression, Pit-1 does not have a role in transactivation of the 'decidua-type' prolactin promoter (Gellersen et al. 1994). Studies of the proximal region of the decidual prolactin promoter have demonstrated that CGAAT/enhancer binding proteins $(\mathrm{C} / \mathrm{EBPs})$ serve as mediators in the delayed cyclic adenosine monophosphate (cAMP) 
signal transduction to the decidua-type prolactin promoter (Pohnke et al. 1999). We demonstrated that the $5^{\prime}$ flanking region of the human prolactin gene between nt -2040 and -1505 acts as an enhancer of gene expression in decidualized endometrial stromal cells (Watanabe et al. 2001). The transcription factors JunD and Fos-related antigen-2 (Fra-2) bind two activator protein-1 (AP-1) response elements in the enhancer, which activates transcription in the decidua but not in other non-decidual cell types.

In a recent study, the expression of Ets-1, Ets-2 and Elfl (Ets-like factor 1) proteins in the human endometrium has been demonstrated to be celland cycle-stage specific, suggesting a putative role for the Ets (E26 transformation-specific/ polyoma virus enhancer) family of transcription factors during decidualization in processes such as cell proliferation and differentiation (Kilpatrick et al. 1999). Several previous reports have shown that expression of prolactin in the human endometrium is a specific marker for decidualization and that endometrial stromal cells must undergo decidualization before the gene is expressed (Gellersen et al. 1994). In this study, we examined whether the Ets transcription factors regulate the expression of decidual prolactin. The Ets transcription factors regulate the expression of a number of genes, including prolactin gene expression in the pituitary gland (Bradford et al. 2000, Schweppe \& Gutierrez-Hartmann 2001). Interaction of Ets-1 and Pit-1 at a composite DNA binding site is required for lactotroph-specific basal rat prolactin promoter activity (Bradford et al. 1997). In addition, Ets also mediates Ras-induced rat prolactin gene transcription (Bradford et al. 1995, Howard \& Maurer 1995, Bradford et al. 2000).

We and other investigators have developed in vitro models of human endometrial stromal cell decidualization, in which the induction of deciduatype prolactin is a marker of this process (Irwin et al. 1989, Tabanelli et al. 1992, Frank et al. 1994, Richards et al. 1995, Brosens et al. 1996, Brar et al. 1999). In this study, we have used primary cultures of endometrial stromal cells and decidual fibroblast cells in which decidualization was induced with the progesterone analog medroxyprogesterone acetate (MPA) and estradiol in combination with dibutyryl cAMP (decidual fibroblasts only).

\section{Materials and methods}

\section{Cell culture}

To prepare primary cultures of endometrial stromal cells, uterine endometrial tissue was obtained from women with normal menstrual cycles at the time of elective tubal ligation. Informed consent was obtained from patients and the Institutional Review Boards of the Children's Hospital Medical Center and the University of Cincinnati approved the study. Proliferative or secretary phase endometrium was removed by suction biopsy and stromal cells were prepared as previously described (Brar et al. 1995). The cells were cultured in DMEM medium containing 2\% fetal bovine serum (FBS), $25 \mathrm{U} / \mathrm{ml}$ penicillin $\mathrm{G}$, $25 \mu \mathrm{g} / \mathrm{ml}$ streptomycin and $2 \cdot 5 \mu \mathrm{g} / \mathrm{ml}$ amphotericin B. To prepare the primary culture of decidual fibroblast cells, term human placenta from cesarean section or vaginal delivery following uncomplicated pregnancies were obtained with institutional Review Board approval from the Children's Hospital Medical Center, Cincinnati, OH, USA. The isolation of cells from decidua parietalis tissue dissected from fetal membranes was begun within 1-2 $\mathrm{h}$ after delivery and the decidual fibroblast cells were prepared as previously described (Richards \& Hartman 1996). After three sub-passages, cells were plated and cultured in RPMI 1640 medium containing 2\% FBS. All other cells were obtained from the American Tissue Culture Collection (Rockville, MD, USA). BeWo choriocarcinoma cells were cultured in Ham's F12 supplemented with $15 \%$ FBS, and HeLa cervical carcinoma cells and JAR choriocarcinoma cells were cultured in RPMI 1640 with 10\% FBS.

\section{Treatment for decidualization}

To induce decidualization in endometrial stromal cells, sub-confluent cultures were grown in media containing $1 \mu \mathrm{M}$ MPA and $10 \mathrm{nM}$ estradiol-17 $\beta$ (estradiol) as previously described (Brar et al. 1995). The medium was changed every third day and experiments were performed on treatment day 14 . To decidualize decidual fibroblast cells, the cultures following cell passage were maintained in media containing $1 \mu \mathrm{M}$ MPA, $10 \mathrm{nM}$ estradiol and $50 \mathrm{nM}$ dibutyryl-cAMP for 12-15 days before performing experiments. All chemicals were purchased from Sigma Chemical Co. 


\section{Nuclear extract preparation}

Nuclear extracts were prepared as previously described (Bohinski et al. 1994, Kelly et al. 1996). Protein concentrations were determined by the Bradford assay method and dye from Bio-Rad, using bovine serum albumin as a standard.

\section{DNase I footprint analysis}

Double-stranded radiolabeled probes (approximately $300 \mathrm{bp}$ ) were generated by end-labeling oligonucleotides encoding a $1.5 \mathrm{~kb}$ region of the decidual-specific promoter with $150 \mu \mathrm{Ci} \gamma\left[{ }^{32} \mathrm{P}\right]$ $(6000 \mathrm{Ci} / \mathrm{mM}$; Perkin-Elmer Life Sciences-NEN, Boston, MA, USA). The DNase I protection assay was performed as previously described (Bohinski et al. 1994, Kelly et al. 1996). The DNA binding reaction was performed on ice, in a $50 \mu \mathrm{l}$ reaction in a buffer containing $10 \mathrm{mM}$ Tris, $\mathrm{pH} 7 \cdot 5,5 \mathrm{mM}$ $\mathrm{MgCl}_{2}, 50 \mu \mathrm{M}$ EDTA, $75 \mathrm{mM} \mathrm{KCl}, 12 \%$ glycerol, $0.5 \mathrm{mM}$ dithiothreitol, and $0.2 \mathrm{mM}$ phenylmethylsulfonyl fluoride. Nuclear extracts $(30 \mu \mathrm{g})$, or BSA (20 $\mu \mathrm{g}$, Boehringer Mannheim) for the naked DNA control, were incubated with $2 \mu \mathrm{g}$ poly $(\mathrm{dl}-\mathrm{dC})$ (Boehringer Mannheim) for $20 \mathrm{~min}$. Then 20000 d.p.m. (approximately $0.3 \mathrm{ng}$ ) of probe were added, and the incubation continued for $1 \mathrm{~h}$. The binding reactions were subjected to DNase I (RQ1 DNase, Promega Corp.) digested for $1.5 \mathrm{~min}$ at room temperature using varying concentrations of DNase (nuclear extract or naked DNA: $0 \cdot 8,0 \cdot 12$ and $0 \cdot 18$ unit/reaction). The reaction was terminated by adding $200 \mu \mathrm{l}$ stop buffer $(100 \mathrm{mM} \mathrm{NaCl}$, $5 \mathrm{mM}$ EDTA, 1\% SDS, $20 \mathrm{mM}$ Tris, $\mathrm{pH} \mathrm{8.0)} \mathrm{and}$ the incubation continued at $50{ }^{\circ} \mathrm{C}$ for $25 \mathrm{~min}$. The DNA fragments were separated on $6 \%$ polyacrylamide, $8 \mathrm{M}$ urea sequencing gels using probe cleaved at guanine and adenine nucleotides with formic acid and piperidine as size markers. Protected regions were detected by comparing the digestion patterns with those of control reactions using BSA in place of nuclear extracts. Putative transcription factor binding sites were determined using Signal Scan (TRANSFAC), a computer program that scans DNA sequences for eukaryotic transcriptional elements (http://bimas.dcrt.nih.gov).

\section{Plasmid constructs}

A plasmid containing the $5^{\prime}$ flanking region of the decidual prolactin gene was constructed by ligating a DNA fragment of the decidual prolactin gene from nt -2927 to +66 (relative to the decidual prolactin initiation site) into pGL3-enhancer (pGL3E, Promega Corp.), as previously described (Watanabe et al. 2001). Using a site-directed mutagenesis kit (Stratagene, La Jolla, CA, USA) and appropriate oligonucleotides with base changes previously described (Logan et al. 1996, Yang et al. 1996, McCarthy et al. 1997), mutations were introduced into Ets motifs within the first $1556 \mathrm{bp}$ of the decidual-specific prolactin promoter (Fig. 1). The wild-type and mutated prolactin promoter oligonucleotides were ligated into the pGL3E plasmid containing a luciferase reporter gene to generate the plasmid referred to as $-1.5 \mathrm{~kb}$ dPRL-luc. After confirming the orientation of these fragments by sequencing with Sequenase Version 2.0 (Amersham Life Science Inc.), these plasmids were used in transient transfection assays. The Ets dominant negative plasmid (kindly obtained from A Gutierrez-Hartmann, Denver, CO, USA) encodes the DNA binding of cEts-2 transactivation domain in the plasmid pAPrEts-Z. The cDNA fragment was inserted into the ATG start codon and introduced into the pSG5 expression plasmid (Stratagene). Expression vectors for pSG5 Ets-1 and pSG5 Ets-2 which encode the p68 chicken cEts-1 and chicken cEts-2 respectively under control of the simian virus 40 early promoter (Wasylyk et al. 1990) were obtained from Bohdan Wasylyk, Strasbourg Cedex, France.

\section{Transient transfection assays}

All DNA plasmids used in transient transfection studies were purified by QIAGEN plasmid Maxi kits (QIAGEN, Vista, CA, USA). The endometrial stromal cells and decidual fibroblast cells were transfected with the luciferase-prolactin promoter constructs at 90-100\% confluency using the calcium phosphate precipitation method (Sambrook et al. 1989). All other cell types used (HeLa, BeWo, and JAR) were transfected by the same method at 60-70\% confluency. Cells cultured in 6-well plates were incubated for $4 \mathrm{~h}$ with $10 \mu \mathrm{g}$ per well luciferase-prolactin promoter constructs. After $4 \mathrm{~h}$, the cells were incubated in growth media and harvested $48 \mathrm{~h}$ after transfection using lysis buffer (TROPIX Inc., Bedford, MA, USA). The cell lysate was centrifuged $(12000 \times \mathbf{g}$ for $5 \mathrm{~min})$ and the supernatant was assayed for luciferase 
$-91$

Ets

$-60$

Wt: GAAAACAGCAAAAACAGGAAGTTCACTCTGTA

Mut1: GAAAACAGCAAAAACACCAAGTTCACTCTGTA

$-774$

Ets

$-745$

Wt: AACTCAAGGAATTATTTAGATTCAGCCATT

Mut: AACTCAACCAATTATTTAGATTCAGCCATT

\author{
$-1003$ \\ Ets \\ $-977$ \\ Wt: GAAAAGATGAATCATTAAGGATTTTCT \\ Mut2: GAAAAGATGAATCATTAACCATTTTCTTTTAATAA
}

\begin{abstract}
$\begin{array}{llll}-1091 & \text { Ets } & \text { Ets } & -1048\end{array}$
Wt: CTGGTTGAGTGTGATGCAAGGGAAAGAAAAGAAAAGGAAATAAA

Mut3:ATGCAAGGGAAAGAAAAGAAAACCAAATAAACTCAACT

Mut5:CTGGTTGAGTGTGATGCAAGCCAAAGAAAAGAAAACCAAATAAACTCAACT Mut4:CTGGTTGAGTGTGATGCAAGCCAAAGAAAAGAAAAGGAAATAAA
\end{abstract}

\author{
$-1267$ \\ Ets \\ $-1237$ \\ Wt: AGAAGTTGAGCCTCAGGATGGTTAATCTTAA \\ Mut6 : AGAAGTTGAGCCTCACCATGGTTAATCTTAA
}

Figure 1 Ets motifs (underlined) in the $5^{\prime}$ flanking region of the decidual-specific prolactin promoter. The wild-type sequence $(\mathrm{Wt})$ and the corresponding oligonucleotides with mutations (Mut) are shown. The mutated bases within Ets motifs are indicated in bold. The mutated oligonucleotides were used for site-directed mutagenesis of the proximal region of the decidual prolactin promoter, to generate mutations of $-1556 \mathrm{dPRL}$ ligated into PGL3E. Mut1-Mut6 refer to mutations shown in the transient transfection assay in Fig. 4.

(Promega Corp.) or $\beta$-galactosidase (TROPIX Inc.) using a Berthold 9501 luminometer (Berthold Systems Inc., Pittsburgh, PA, USA). All transfection results were normalized to $\beta$-galactosidase activity resulting from co-transfection of $0.5 \mu \mathrm{g}$ per well of pSV-ßgal (Promega Corp.). The values represent the means \pm S.E.M. of triplicate wells. All transfections were performed in at least three separate experiments.

\section{Electrophoretic mobility shift assays (EMSAs)}

Gel shift assays were performed as previously described (Bohinski et al. 1994, Kelly et al. 1996). Nuclear extracts $(5-10 \mu \mathrm{g})$ were incubated for $10 \mathrm{~min}$ at room temperature in buffer containing

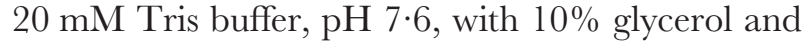
$40 \mathrm{ng} / \mathrm{ml}$ poly(dl-dC) (Boehringer Mannheim). A double stranded ${ }^{32}$ P-labeled oligonucleotide probe (100 000 d.p.m.) encoding DNA fragments of the prolactin promoter which was gel purified (BIO 101 MERmaid kit, Vista, CA, USA) was added and the incubation continued for an additional $10 \mathrm{~min}$. Where indicated, 100-fold molar excess competing non-labeled oligonucleotides, oligonucleotides containing mutations of the Ets consensus sites in footprinted regions of the - 1556 bp promoter or synthetic oligonucleotides containing presumptive Ets binding sites, were added along with the probe to determine the specificity of binding. Mutated oligonucleotides were generated using mutated oligonucleotides with a Quick Change Site-Directed Mutagenesis Kit (Stratagene, La Jolla, CA, USA). The presence of the expected mutations was verified by sequencing (Sequenase Version 2.0, Amersham Pharmacia Biotech.). The synthetic oligonucleotides containing presumptive Ets binding sites (underlined) were purchased from Santa Cruz Biotechnology Inc. (Santa Cruz, CA, USA) for 
tests of specificity in EMSAs. These were a wild-type oligonucleotide GATCTCGAGGAGGA AGTTCGA and an oligonucleotide with the Ets sequence mutated (mutated bases in bold) GATG TCGAGGAAGAAGTTCGA. The oligonucleotide for $n t-86 /-68$ of the 5 ' flanking region of decidual prolactin, in which the Ets consensus site is underlined, is as follows: CAGCAAAAACAGGAA GTTC. The reaction mixture was electrophoresed on a $5 \%$ polyacrylamide gel in $0.5 \times \mathrm{TBE}$ to separate bound and free probes.

For supershift-interference assays, nuclear extracts were incubated for $10 \mathrm{~min}$ at room temperature with the appropriate antibody prior to addition of the radiolabeled probe using the protocol outlined above. Antibodies to Ets-1/Ets-2 were purchased from Santa Cruz Biotechnology Inc., and used according to the instructions provided.

\section{Western blot analysis}

Cell extracts prepared from primary cultures of endometrial stromal cells treated for 3, 6, 9 and 12 days and untreated cells were analyzed by Western blotting as previously described (Brar et al. 1995). A rabbit polyclonal antibody raised against a peptide mapping within the carboxy terminal domain of Ets-1 p54 of human origin (C275; Santa Cruz Biotechnology Inc.) was used. This antibody cross-reacts with several members of the Ets family. To detect Ets immunoreactivity, anti-rabbit IgGhorse radish peroxidase (Chemicon, Temecula, CA, USA) was visualized using an enhanced chemiluminescent substrate kit (SuperSignal West Pico Chemiluminescent Substrate; Pierce, Rockford, IL, USA) and autoradiography. The autoradiographic signals were quantitated using Kodak Digital Science 1D Image Analysis Software (Eastman Kodak Company).

\section{Statistical analysis}

Statistical differences between group means were determined by analysis of variance with Bonferroni adjustment or a Student's t-test, depending on design. Differences were considered significant when $P<0 \cdot 01$. The data are presented as the mean \pm S.E.M.

\section{Results}

Transfection studies were performed to determine whether the Ets family proteins Ets-1 and Ets-2 transactivate the decidual prolactin promoter. As shown in Fig. 2, co-transfection of pSG5 Ets-1 and $-1.5 \mathrm{~kb}$ dPRL-luc in BeWo cells or JAR cells, which do not express endogenous Ets mRNA (Fig. 2A), resulted in a 3- to 5-fold increase in luciferase activity (Fig. 2B). Similar results were obtained in co-transfection experiments using pSG5 Ets-1 and a plasmid containing the minimal promoter region of the decidual prolactin gene (-314 bp dPRL-luc). In contrast to pSG5 Ets-1, overexpression of pSG5 Ets-2 had relatively little or no effect on $-1.5 \mathrm{~kb}$ dPRL-luc or $-314 \mathrm{bp}$ dPRL-luc in BeWo and JAR cells. Furthermore, co-transfection of pSG5 Ets-1 and pSG5 Ets-2 together had no greater effect on luciferase activity than pSG5 Ets-1 alone (data not shown). Co-transfection of $-1.5 \mathrm{~kb}$ dPRL-luc with a dominant negative mutant of Ets (pAPrEtsZ) that lacks a transactivation domain resulted in a dose-dependent inhibition of luciferase activity (Fig. 3). Co-transfection of Ets-1 or Ets-2 into undecidualized decidual fibroblast cells and endometrial stromal cells along with $-1.5 \mathrm{~kb}$ dPRL-luc or -314 bp dPRL-luc had no effect on luciferase activity, indicating that Ets-1 and Ets-2 are not sufficient for the induction of prolactin gene expression in undecidualized cells (data not shown).

There are six putative Ets binding sites within the proximal $1.5 \mathrm{~kb}$ of the decidual-specific promoter located $5^{\prime}$ of exon $1 \mathrm{~A}$ that are located at $\mathrm{nt}$ $-77 /-71,-769 /-764,-987 /-982,-1058 /-1053$, $-1071 /-1068$ and $-1254 /-1248$. To determine whether one or more of the putative Ets motifs is essential for the transactivation of the prolactin promoter, we examined the role of each of these Ets motifs in the decidual prolactin promoter by site-directed mutagenesis. Decidual fibroblast cells were transfected with the plasmid containing the prolactin promoter $(-1.5 \mathrm{~kb}$ dPRL-luc) with a mutation within the Ets motif (Fig. 1). As shown in Fig. 4, mutation of the Ets motif at nt $-77 /-71$ almost completely $(91 \cdot 2 \%)$ abolished the basal expression of the prolactin promoter, while mutations of the other Ets motifs had much less effect. In addition, Ets- 1 and Ets-2 had no effect on the luciferase activity of the prolactin promoter containing the mutated Ets motif (data not shown). 
A

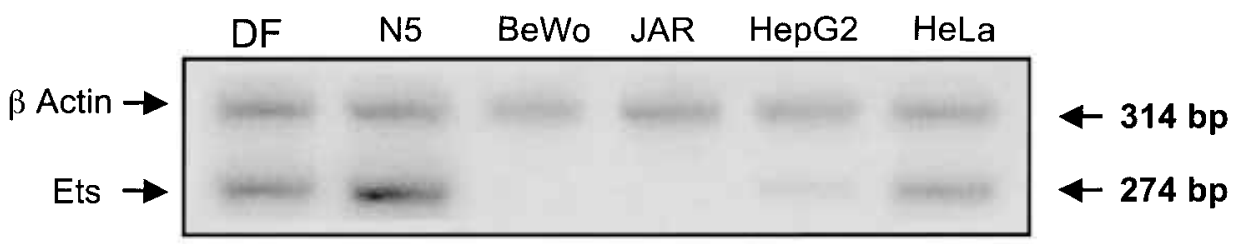

B
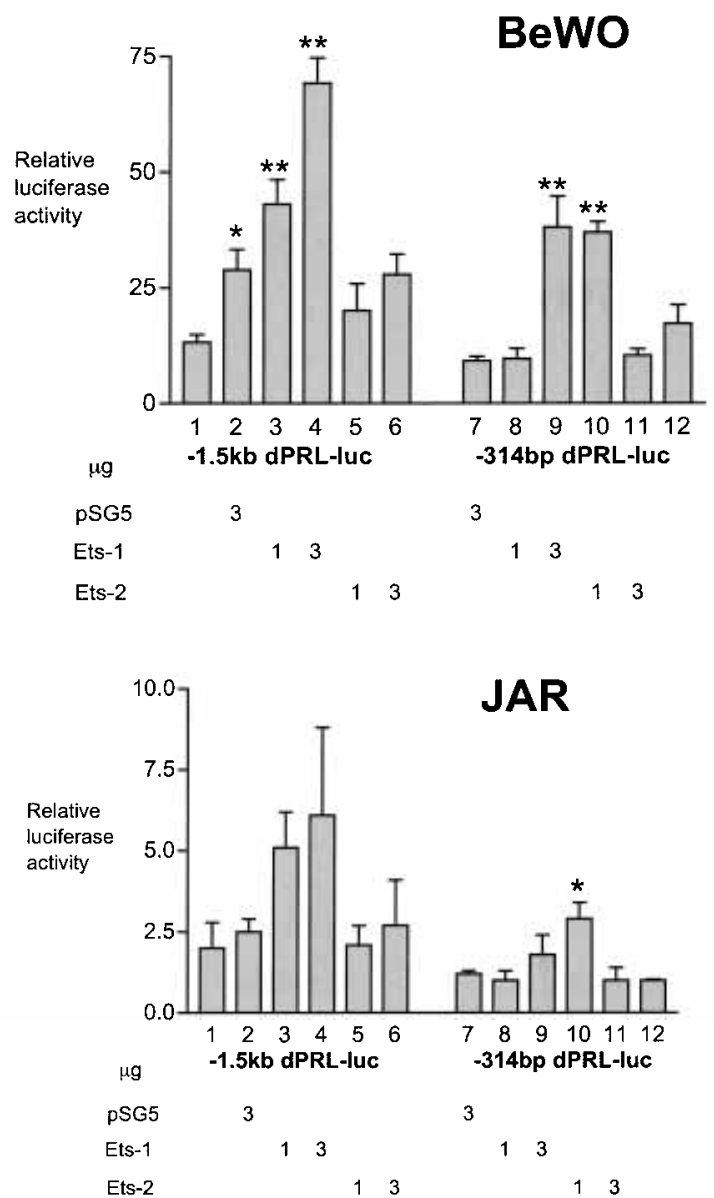

Figure 2 Stimulation of the decidual prolactin promoter by pSG5 Ets-1 in cells that do not express Ets-1 mRNA. (A) PCR analysis of Ets mRNA transcripts in different cell types shows no expression in BeWo and JAR cells (274 bp transcript). Ets-1 mRNA was highly expressed in decidual fibroblasts (DF), endometrial N5 cells (N5) and HeLa cells. Co-amplification of $\beta$-actin mRNA in the same samples (314 bp transcript) was used as an internal control. (B) Basal expression of the -1556 bp decidual prolactin promoter or the basal promoter ( $-314 \mathrm{bp})$ linked to luciferase $(-1.5 \mathrm{~kb} \mathrm{dPRL}-\mathrm{luc}$ and $-314 \mathrm{bp}$ dPRL-luc), was stimulated in BeWo and JAR cells by pSG5 Ets-1 $(1 \mu \mathrm{g}$ or $3 \mu \mathrm{g})$. In contrast, overexpression of pSG5 Ets-2 has relatively little effect on basal prolactin promoter activity compared with pSG5 Ets-1. Each value in the data shows the mean \pm S.E.M. of triplicate wells in one experiment. These experiments were repeated more than three times. ${ }^{*} P<0.01$ and ${ }^{*} P<0.001$ compared with control $(-1.5 \mathrm{~kb}$ dPRL-luc or -314 bp dPRL-luc) in each cell type. 


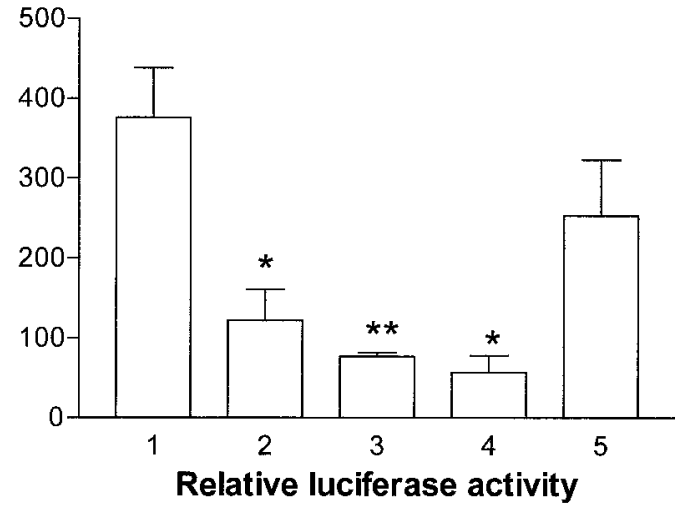

$\begin{array}{rccccc}\text { pAPrEts-Z } & - & 1 \mu \mathrm{g} & 3 \mu \mathrm{g} & 6 \mu \mathrm{g} & - \\ \text { vector } & - & - & - & - & 3 \mu \mathrm{g}\end{array}$

Figure 3 Transfection of an Ets dominant negative suppresses decidual prolactin promoter activity. A dose-dependent suppression of $-1.5 \mathrm{~kb} \mathrm{dPRL}$-luc activity was seen in decidual fibroblasts co-transfected with the promoter and a dominant negative for Ets (pAPrEts-Z). There was no significant suppression of promoter activity upon co-transfection with the empty vector. The data show the mean \pm S.E.M. of triplicate wells in one experiment. These experiments were repeated more than three times. ${ }^{*} P<0.01$ compared with $-1.5 \mathrm{~kb}$ dPRL-luc alone in the absence of pAPrEts-Z, ${ }^{* \star} P<0.05$ compared with $-1.5 \mathrm{~kb}$ dPRL-luc alone.
On the other hand, mutation of each of the other Ets motifs (Mut2-Mut6) in the proximal $1.5 \mathrm{~kb}$ of the prolactin promoter had little or no effect on basal promoter activity. Mutation of two adjacent Ets motifs at nt $-1053 / 1058$ and $-1071 / 1068$ (Mut5) did not affect luciferase expression any more than mutation of one site alone (Mut4).

DNAse 1 footprint analysis was subsequently performed to determine whether the Ets motif at nt $-77 /-71$ is located in a footprinted region of the promoter. The analysis utilized oligonucleotide probes encoding the $5^{\prime}$ flanking region of the decidual-specific exon (1A) and nuclear extracts from primary cultures of endometrial stromal cells (ESC) decidualized in vitro with MPA and estradiol. As shown in Fig. 5, a footprinted region was detected at $n t-86 /-68$ that contains the consensus Ets site (boxed sequence). The other Ets motifs in the proximal $1.5 \mathrm{~kb}$ of the promoter were not contained within footprinted regions. Computer analysis revealed that the footprinted region contained putative binding sites for Ets-1 and four other members of the Ets transcription factor family (TCF-2- $\alpha$, Fli-1, EF-1A and PEA3) and for T-cell transcription factor-1.

Since the Ets motif located at nt $-77 /-71$ is important in the transactivation of the decidual
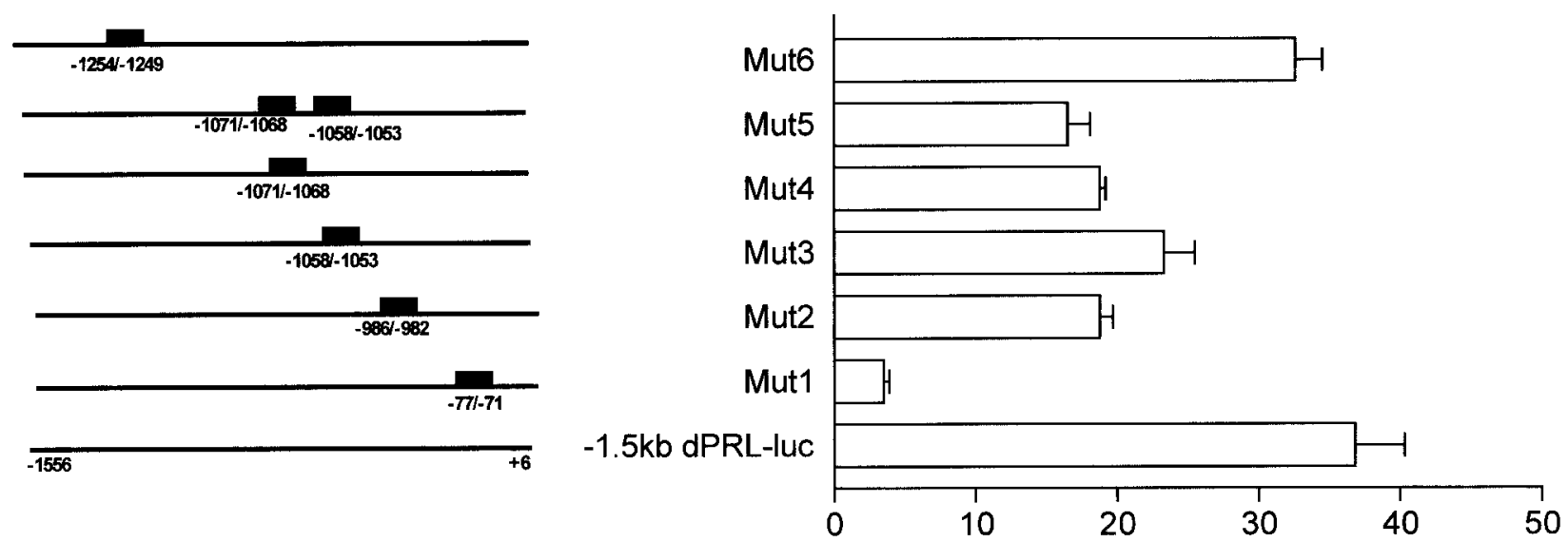

Relative luciferase activity

Figure 4 Mutation analysis of Ets motifs in the decidual-specific promoter. Relative luciferase activity is shown in transient transfection assays of decidual fibroblasts transfected with the decidual-specific prolactin promoter ligated into pGL3E (-1.5 kb dPRL-luc). The $-1.5 \mathrm{~kb}$ dPRL-luc constructs with mutations (Mut1-Mut6) of Ets motifs (filled boxes) is shown schematically on the left (for details of bases mutated see Fig. 1). In similar experiments, there was also no change in luciferase activity upon mutation of the Ets motif at nt $-769 /-764$ compared with $-1.5 \mathrm{~kb}$ dPRL-luc (data not shown). The data shown are the mean \pm S.D. of triplicate wells in one experiment. These experiments were repeated more than three times. 


\section{BSA ESC G/A}

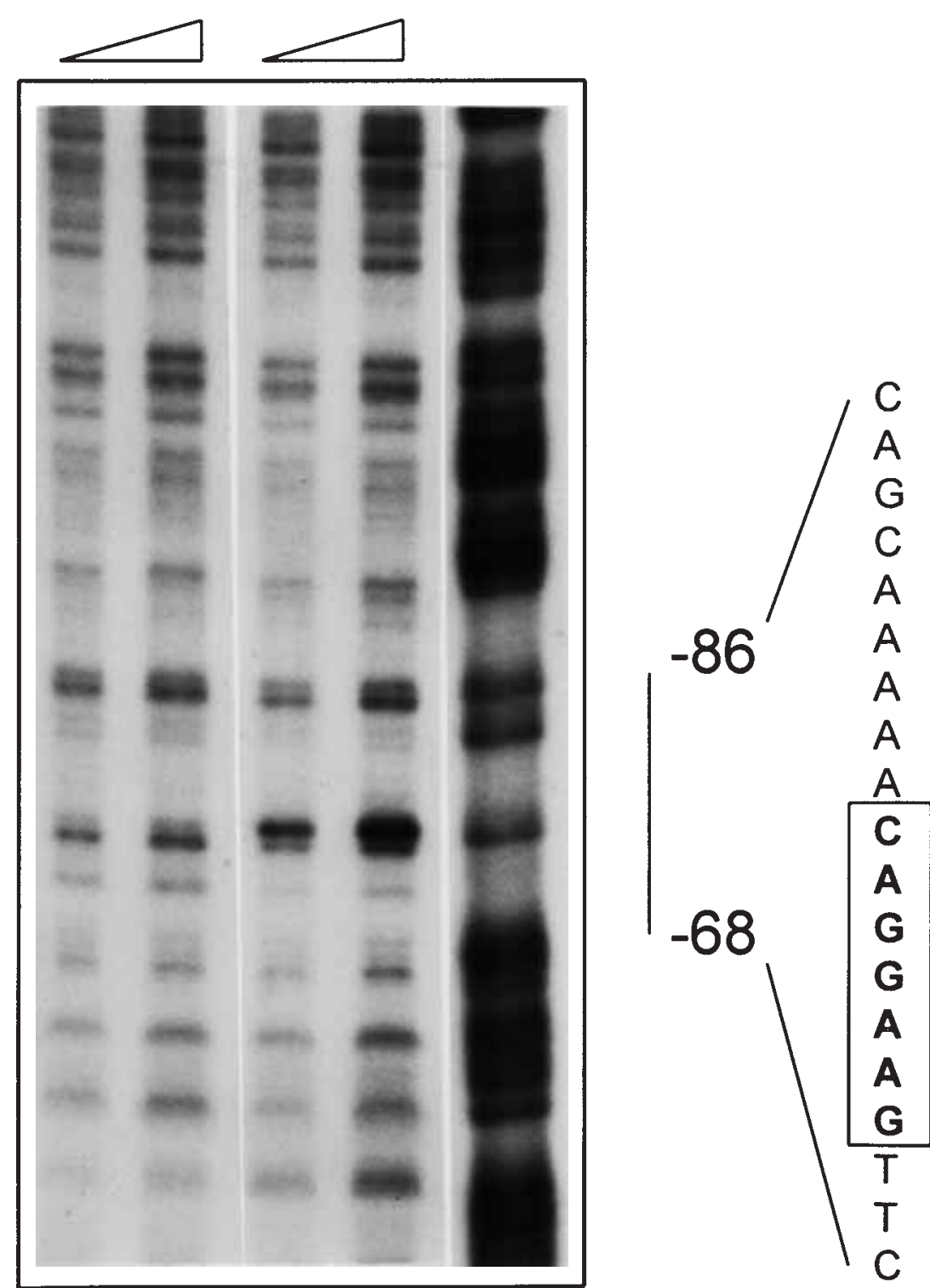

Figure 5 DNase I footprint analysis of the proximal region (nt $-309 /+16)$ of the decidual prolactin promoter. Shown is the in vitro DNase I digestion pattern performed using nuclear extracts from decidualized endometrial stromal cells (ESC). The bar on the right indicates the position of the protected region on the decidual prolactin promoter. The footprinted region between nt -86/-68 (CAGCAAAAACAGGAAGTTC) encodes a putative Ets binding site at nt $-77 /-71$ (in a box in bold). On the left is shown a lane with $\mathrm{BSA}$, which was used as a control and on the right, a radiolabeled $\mathrm{G} / \mathrm{A}$ ladder. These experiments were repeated more than three times.

prolactin promoter, we next examined the binding of cellular proteins to the Ets motif. As shown in Fig. 6, gel shift assays using radiolabeled oligonucleotides encoding the Ets motif and nuclear extracts from treated decidual fibroblast cells revealed two major retarded complexes 
(lane 1, arrows). Both retarded complexes were competed by excess unlabeled probe encoding the decidual-specific promoter (lane 2) and by an oligonucleotide with a presumptive Ets binding site (lane 4). However, the formation of the complexes was not competed by oligonucleotide probes in which the Ets motif was mutated in the decidual-specific promoter or the presumptive Ets binding site (lanes 3 and 5 respectively). Supershift analysis performed using antiserum to Ets-1/Ets-2 demonstrated that the binding of the decidual prolactin probe was competed in the presence of the antiserum (lane 6).

During the differentiation of endometrial stromal cells to decidual cells, there is a marked induction of prolactin gene expression. To determine whether Ets proteins also increase during decidualization, Western blot analyses using an antiserum to Ets-1/Ets-2 and an antiserum specific to Ets-2 were performed on cell extracts of endometrial stromal cells decidualized in vitro with MPA and estradiol. As shown in Fig. 7, upon treatment of ESC with MPA and estradiol to induce decidualization, a single protein band was detected by the antiserum to Ets-1/Ets-2 that increased 9- to 20-fold between day 1 and day 12 respectively compared with day 0 . The apparent molecular mass of the band detected by the Ets-1/Ets-2 antiserum ( $54 \mathrm{kDa})$ corresponds to the known molecular mass of Ets-1 (Ghysdael et al. 1986).

\section{Discussion}

Several lines of evidence strongly suggest that Ets-1 is critical for basal expression of the decidual prolactin gene. Overexpression of Ets-1 significantly induces decidual prolactin promoter activity in BeWo, JAR and HepG2 cells that express little or no endogenous Ets-1. Furthermore, a dominant/negative mutant of Ets represses basal promoter activity. Although the proximal $1.5 \mathrm{~kb}$ of the decidual prolactin promoter contains six Ets motifs, only the Ets motif at nt $-77 /-71$ is essential for basal gene expression. The other Ets motifs have little or no role in basal gene expression. Mutation of the Ets motif at nt $-77 /-71$ results in an approximately 90\% decrease in promoter activity, while mutations of the other Ets motifs result in only small changes. The Ets motif at nt $-77 /-71$ is contained within a footprinted region of the promoter in the 314 bp proximal region of the promoter shown by us and others to be critical for minimal basal expression. The other Ets motifs are not within footprinted regions. Although Ets-1 and Ets-2 share 95\% homology in the DNA binding domain and bind to similar sequences (Watson et al. 1988, Woods et al. 1992), overexpression of Ets-2 was not as potent as Ets-1 in stimulating decidual prolactin promoter activity. In addition, Ets-2 did not enhance the stimulation of promoter activity by Ets-1. Other Ets transcription factor family members may also stimulate prolactin promoter activity since computer analysis of the footprinted region (nt -86/-68) indicated the presence of putative binding sites for four other members of the Ets transcription factor family. At present it is not known which of these other Ets transcription factors are expressed in decidualized endometrial cells. Although Ets-1 induces prolactin gene expression in decidualized cells, Ets-1 alone is not sufficient to induce prolactin gene expression in undecidualized endometrial stromal and fibroblast cells.

Gel shift assays demonstrated that an oligonucleotide containing the sequence of the proximal Ets motif forms specific DNA-protein complexes with nuclear extracts from decidualized endometrial stromal cells. An antiserum to Ets-1/Ets-2 competes the bound complex, confirming that Ets binds to the DNA motif. Western blot analyses of nuclear extracts of endometrial stromal cells at various stages of decidualization with an antiserum to Ets-1/Ets-2 showed that Ets protein levels markedly increased during decidualization with a pattern of expression that paralleled the expression of prolactin. The apparent molecular mass of the single band detected by the antiserum corresponds to the known molecular mass of Ets-1 (Ghysdael et al. 1986). Taken together, the findings of this study suggest that Ets-1 may also be involved in the induction of prolactin and other genes during decidualization. Ets controls the expression of a number of genes involved in extracellular remodeling, including tissue inhibitor of metalloproteinases-1 (TIMP-1), tenascin-C and collagen type 1 (Logan et al. 1996, Trojanowska 2000). In the mouse endometrium, Ets-1 which positively regulates the expression of urokinase plasminogen activator 1 gene, is co-expressed in the maternal decidua with this protease, suggesting that Ets may regulate vascular reorganization in the 


\section{COMPETITORS}

dPRL promoter $(-86 /-68)$

Ets mutant $(-77 /-71)$

Ets consensus

Ets consensus mutant

Ets antibody

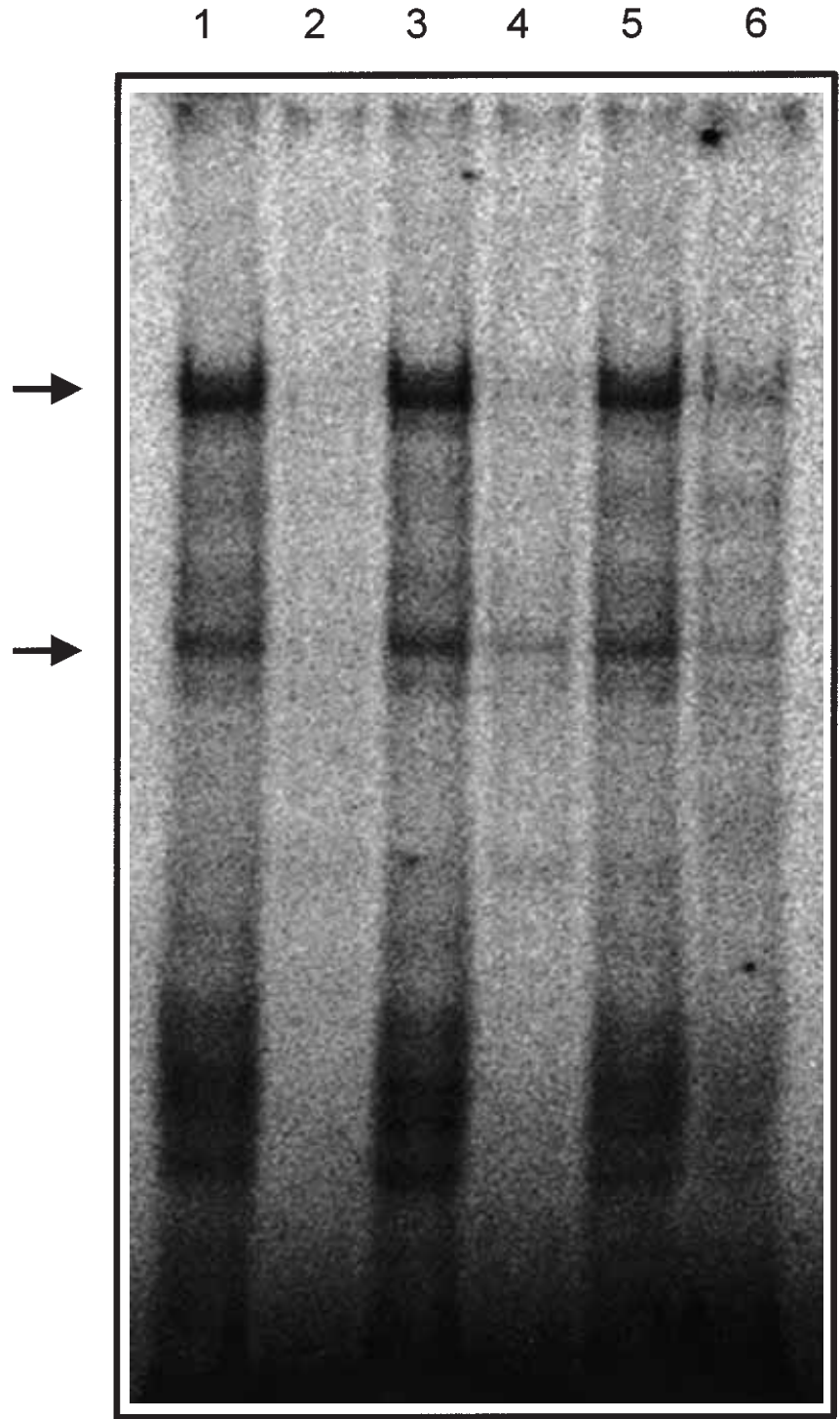




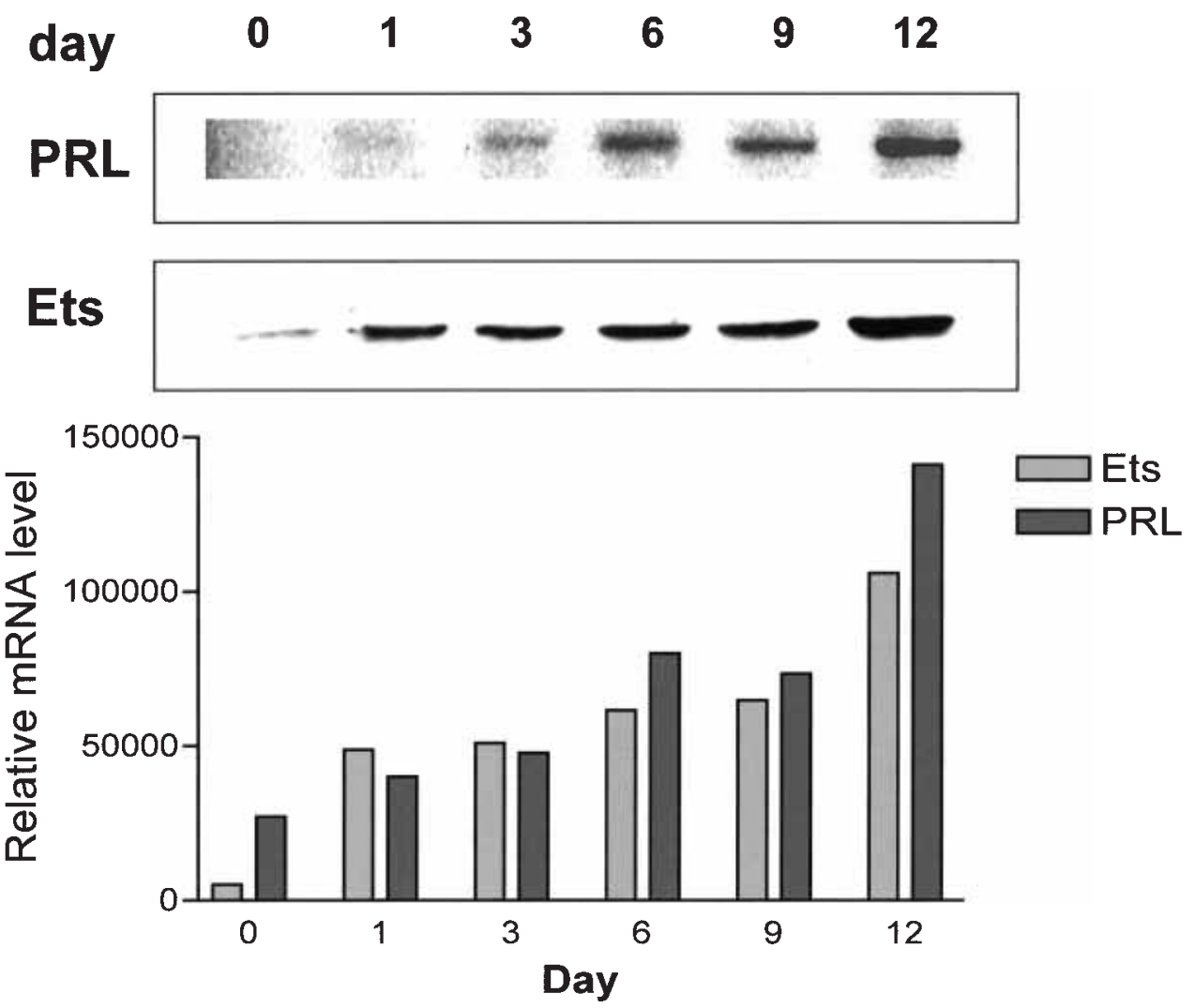

Figure 7 Western blot analysis of endometrial stromal cells showing Ets immunoreactivity during decidualization. Untreated endometrial stromal cells express low levels of Ets (day 0). Decidualization was induced by treatment of endometrial stromal cells with MPA and estradiol as described in Methods. A specific immunoreactive band detected (54 kDa size) by Western blot analysis of cell extracts prepared at days 1, 3, 6, 9 and 12 days of treatment is shown (top panel). Densitometric analysis of the relative intensity of the bands indicated graphically (lower panel) shows Ets protein expression increased 9- to 20 -fold between day 1 and day 12 respectively compared with day 0 . These changes were highly reproducible using endometrial stromal cell extracts from different patients.

region (Grevin et al. 1993, Nakada et al. 1999). The expression of Ets has been demonstrated to correlate with the occurrence of invasive processes during normal and pathological development. For example, expression of cEts in endometrial carcinoma 1 correlates with the malignant potential of this tumor (Takai et al. 2000). Therefore, the Ets transcription factors play a role in regulating numerous signaling pathways in the endometrium and decidua.

Figure 6 Electrophoretic mobility shift analysis of the footprinted region in the decidual prolactin promoter. Nuclear extracts of decidualized endometrial stromal cells were incubated with a ${ }^{32} \mathrm{P}$-labeled double stranded oligonucleotide encoding $n t-86 /-68$ of the decidua-type prolactin promoter in the presence of different unlabeled competitor oligonucleotides. Lane 1, no competitor; lane 2, oligonucleotide encoding nt $-86 /-68$ of the decidua-type prolactin promoter (dPRL promoter -86/-68); lane 3, oligonucleotide containing a mutation in the Ets motif at $n t-77 /-71$ of the decidua-type prolactin promoter (Ets mutant -78/-70); lane 4, oligonucleotide containing a presumptive Ets binding site (Ets consensus); lane 5, oligonucleotide containing a mutation in the presumptive Ets binding site (Ets consensus mutant); lane 6, competition with antiserum to Ets-1/Ets-2 (Ets antibody). The arrows indicate the specific Ets complexes. These experiments were repeated three times. Identical gel sift assays were obtained using extracts from decidualized endometrial stromal cells (data not shown). 
Transcription factors of the Ets family have not been reported to form homo- or heterodimers. Instead, combinatorial control involving an interaction between Ets and other key transcription factors is frequently observed with Ets family members (Crepieux et al. 1994, Sharrocks et al. 1997, Li et al. 2000). For example, transcriptional activation of the $f t-1$ promoter requires the cooperation of an Ets motif and a cAMP response element or CRE. Cooperation of Ets with AP-1 has been shown in promoters of the genes as TIMP-1 (Logan et al. 1996), and the enhancer of human urokinase-type plasminogen activator gene, in which the ability of Ets proteins to activate transcription relies on the presence of an adjacent AP-1 transcription factor as a partner (Cirillo et al. 1999, Sun \& Duckworth 1999). A direct physical association between Ets and AP-1 transcription factors plays an important role in regulating the expression of a number of mammalian genes (Buttice et al. 1996). To determine whether mutation of AP-1 sites located adjacent to Ets motifs in the decidual prolactin promoter (at nt $-769 /-764,-1071 /-1068$ and $-1254 /-1248)$ occurred, constructs with mutations in both the individual Ets and their adjacent AP-1 sites were transfected. In these experiments, the mutations of adjacent Ets and AP-1 sites together had no effect on luciferase activity (data not shown), as seen upon mutation of the individual Ets motifs alone. There is no $\mathrm{AP}-1$ site in close proximity to the critical Ets motif at nt $-77 /-71$; an AP-1 binding site is located at a distance of greater than $500 \mathrm{bp}$ upstream. This suggests that it is unlikely that there is a physical interaction between Ets binding at this site and AP-1 at an adjacent site. However, our studies do not completely rule out a synergistic transcriptional regulation by Ets motifs and AP-1 due to protein-protein interaction.

The ability of Ets proteins to activate transcription, however, does not always depend on the presence of adjacent AP-1 transcription factor binding sites. Members of the Ets family show functional synergism and in some cases, direct interaction with many transcription factors to achieve selective and efficient activation of their target genes (Crepieux et al. 1994, Nakae et al. 1995). For instance, regulation of the human interleukin- 5 promoter by Ets- 1 and Ets- 2 requires the T-cell specific transcription factor, GATA3 (Blumenthal et al. 1999). Sp1 and Sp3 are co-factors of Ets in the regulation of extracellular matrix genes (Shirasaki et al. 1999, Trojanowska 2000) and composite Ets/Pit-1 binding sites in the prolactin gene expression in the pituitary mediate transcriptional responses to multiple signaling pathways (Howard \& Maurer 1995, Bradford et al. 2000). p300/CBP increases transcriptional activation by Ets- 1 and Ets-2 in a number of genes, including the stromelysin promoter (Jayaraman et al. 1999). We had previously demonstrated that binding of the transcription factors JunD and Fra-2 to response elements in the decidual prolactin enhancer was stimulated by p300. In our studies, there is no evidence that AP-1 family members or p300 enhance the effects of Ets-1 on decidual prolactin promoter activity.

Taken together, the results of this study indicate that an Ets binding site between nt $-77 /-71$ of the decidual prolactin promoter, located within a region previously demonstrated to be the minimal promoter, is essential for basal expression of the decidual prolactin gene.

\section{Acknowledgements}

This work was supported by NIH grant HD-15201. The authors would like to thank Michael Hubert for technical assistance and Drs Nelson Horseman and Arthur Buckley for critical review of this manuscript.

\section{References}

Berwaer M, Martial JA \& Davis JRE 1994 Characterization of an upstream promoter directing extrapituitary expression of the human prolactin gene. Molecular Endocrinology 8 635-642.

Blumenthal SG, Aichele G, Wirth T, Czernilofsky AP, Nordheim A \& Dittmer J 1999 Regulation of the human interleukin-5 promoter by Ets transcription factors. Ets1 and Ets-2, but not Elf-1, cooperate with GATA3 and HTLV-I Taxl. Journal of Biological Chemistry 274 12910-12916.

Bohinski RJ, Di Lauro R \& Whitsett JA 1994 The lung-specific surfactant protein $\mathrm{B}$ gene promoter is a target for thyroid transcription factor 1 and hepatocyte nuclear factor 3 , indicating common factors for organ-specific gene expression along the fore-gut axis. Molecular and Cellular Biology 14 5671-5681.

Bradford AP, Conrad KE, Wasylyk C, Wasylyk B \& Gutierrez-Hartmann A 1995 Functional interaction of c-Ets-1 and GHF-1/Pit-1 mediates Ras activation of pituitary-specific gene expression: mapping of the essential c-Ets-1 domain. Molecular and Cellular Biology 15 2849-2857.

Bradford AP, Wasylyk C, Wasylyk B \& Gutierrez-Hartmann A 1997 Interaction of Ets-1 and the POU-homeodomain protein GHF-1/Pit-1 reconstitutes pituitary-specific gene expression. Molecular and Cellular Biology 17 1065-1074. 
Bradford AP, Brodsky KS, Diamond SE, Kuhn LC, Liu Y \& Gutierrez-Hartmann A 2000 The Pit-1 homeodomain and beta-domain interact with Ets-1 and modulate synergistic activation of the rat prolactin promoter. Fournal of Biological Chemistry 275 3100-3106.

Brar AK, Frank GR, Richards RR, Meyer AJ, Kessler CA, Cedars MI, Klein DJ \& Handwerger S 1995 Laminin decreases PRL and IGFBP-1 expression during in vitro decidualization of human endometrial stromal cells. Fournal of Cellular Physiology 163 30-37.

Brar AK, Kanda Y, Kessler CA, Cedars MI \& Handwerger S 1999 N5 endometrial stromal cell line: a model system to study decidual prolactin gene expression. In Vitro Cellular and Developmental Biology - Animal 35 150-154.

Brosens JJ, Takeda S, Acevedo CH, Lewis MP, Kirby PL, Symes EK, Krausz T, Purohit A, Gellersen B \& White JO 1996 Human endometrial fibroblasts immortalized by simian virus 40 large $\mathrm{T}$ antigen differentiate in response to a decidualization stimulus. Endocrinology 137 2225-2231.

Buttice G, Duterque-Coquillaud M, Basuyaux JP, Carrere S, Kurkinen M \& Stehelin D 1996 Erg, an Ets-family member, differentially regulates human collagenasel (MMP1) and stromelysin 1 (MMP3) gene expression by physically interacting with the Fos/Jun complex. Oncogene 13 2297-2306.

Cirillo G, Casalino L, Vallone D, Caracciolo A, De Cesare D \& Verde P 1999 Role of distinct mitogen-activated protein kinase pathways and cooperation between Ets-2, ATF-2, and Jun family members in human urokinase-type plasminogen activator gene induction by interleukin-1 and tetradecanoyl phorbol acetate. Molecular and Cellular Biology 19 6240-6252.

Crepieux P, Coll J \& Stehelin D 1994 The Ets family of proteins: weak modulators of gene expression in quest for transcriptional partners. Critical Review of Oncology 5 615-638

DiMattia GE, Gellersen B, Duckworth ML \& Friesen HG 1990 Human prolactin gene expression. The use of an alternative noncoding exon in decidua and the IM-9-lymphoblast cell line. Journal of Biological Chemistry 265 16412-16421.

Frank GR, Brar AK, Cedars MI \& Handwerger S 1994 Prostaglandin $\mathrm{E}_{2}$ enhances human endometrial stromal cell differentiation. Endocrinology 134 258-263.

Gellersen B, DiMattia GE, Friesen HG \& Bohnet HG 1989 Prolactin (PRL) mRNA from human decidua differs from pituitary PRL mRNA but resembles the IM-9-P3 lymphoblast PRL transcript. Molecular and Cellular Endocrinology 64 127-130.

Gellersen B, Kempf R, Telgmann R \& DiMattia GE 1994 Nonpituitary human prolactin gene transcription is independent of Pit-1 and differentially controlled in lymphocytes and in endometrial stroma. Molecular Endocrinology 8 356-373.

Ghysdael J, Gegonne A, Pognonec P, Dernis D, Leprince D \& Stehelin D 1986 Identification and preferential expression on thymic and bursal lymphocytes of a $c$-ets oncogene-encoded $M_{\mathrm{r}}$ 54000 cytoplasmic protein. PNAS 83 1714-1718.

Grevin D, Chen JH, Raes MB, Stehelin D, Vandenbunder B \& Desbiens X 1993 Involvement of the proto-oncogene c-ets 1 and the urokinase plasminogen activator during mouse implantation and placentation. International Fournal of Developmental Biology $\mathbf{3 7}$ 519-529.

Handwerger S \& Brar A 2001 Human uteroplacental lactogens: physiology and molecular biology. In Prolactin, ch 9, pp 169-187. Ed ND Horseman. Boston, MA, USA: Kluwer Academic Publishers.

Hiraoka Y, Tatsumi K, Shiozawa M, Aiso S, Fukasawa T, Yasuda K \& Miyai K 1991 A placenta-specific 5' non-coding exon of human prolactin. Molecular and Cellular Endocrinology 75 71-80.

Howard PW \& Maurer RA 1995 A composite Ets/Pit-1 binding site in the prolactin gene can mediate transcriptional responses to multiple signal transduction pathways. Fournal of Biological Chemistry $27020930-20936$
Irwin JC, Kirk D, King RJ, Quigley MM \& Gwatkin RB 1989 Hormonal regulation of human endometrial stromal cells in culture: an in vitro model for decidualization. Fertility and Sterility $\mathbf{5 2}$ $761-768$.

Jayaraman G, Srinivas R, Duggan C, Ferreira E, Swaminathan S, Somasundaram K, Williams J, Hauser C, Kurkinen M, Dhar R, Weitzman S, Buttice G \& Thimmapaya B 1999 p300/cAMP-responsive element-binding protein interactions with ets- 1 and ets-2 in the transcriptional activation of the human stromelysin promoter. Fournal of Biological Chemistry $\mathbf{2 7 4}$ 17342-17352.

Kelly SE, Bachurski CJ, Burhans MS \& Glasser SW 1996 Transcription of the lung-specific surfactant protein $\mathrm{C}$ gene is mediated by thyroid transcription factor 1. Fournal of Biological Chemistry 271 6881-6888.

Kilpatrick LM, Kola I \& Salamonsen LA 1999 Transcription factors Ets-1, Ets-2, and Elf1 exhibit differential localization in human endometrium across the menstrual cycle and alternate isoforms in cultured endometrial cells. Biology of Reproduction $\mathbf{6 1}$ 120-126.

Li R, Pei H \& Watson DK 2000 Regulation of Ets function by protein-protein interactions. Oncogene 19 6514-6523.

Logan SK, Garabedian MJ, Campbell CE \& Werb Z 1996 Synergistic transcriptional activation of the tissue inhibitor of metalloproteinases-1 promoter via functional interaction of AP-1 and Ets-1 transcription factors. Fournal of Biological Chemistry 271 774-782.

McCarthy SA, Chen D, Yang BS, Garcia Ramirez JJ, Cherwinski H, Chen XR, Klagsbrun M, Hauser CA, Ostrowski MC \& McMahon M 1997 Rapid phosphorylation of Ets-2 accompanies mitogen-activated protein kinase activation and the induction of heparin-binding epidermal growth factor gene expression by oncogenic Raf-1. Molecular and Cellular Biology 17 2401-2412.

Nakada M, Yamashita J, Okada Y \& Sato H 1999 Ets-1 positively regulates expression of urokinase-type plasminogen activator (uPA) and invasiveness of astrocytic tumors. Foumal of Neuropathology and Experimental Neurology 58 329-334.

Nakae K, Nakajima K, Inazawa J, Kitaoka T \& Hirano T 1995 ERM, a PEA3 subfamily of Ets transcription factors, can cooperate with c-Jun. Fournal of Biological Chemistry 270 23795-23800.

Pohnke Y, Kempf R \& Gellersen B 1999 CGAAT/enhancer-binding proteins are mediators in the protein kinase A-dependent activation of the decidual prolactin promoter. Fournal of Biological Chemistry 274 24808-24818.

Richards RG \& Hartman SM 1996 Human dermal fibroblast cells express prolactin in vitro. Fournal of Investigational Dermatology 106 $1250-1255$.

Richards RG, Brar AK, Frank GR, Hartman SM \& Hiroaki J 1995 Fibroblast cells from term human decidua closely resemble endometrial stromal cells: induction of prolactin and insulin-like growth factor binding protein-1 expression. Biology of Reproduction 52 609-615.

Sambrook J, Fritsch EF \& Maniati T 1989 Molecular Cloning - A Laboratory Manual. New York, USA: Cold Spring Harbor Laboratory Press

Schweppe RE \& Gutierrez-Hartmann A 2001 Pituitary Ets-1 and GABP bind to the growth factor regulatory sites of the rat prolactin promoter. Nucleic Acids Research 29 1251-1260.

Sharrocks AD, Brown AL, Ling Y \& Yates PR 1997 The ETS-domain transcription factor family. International fournal of Biochemestry and Cell Biology 29 1371-1387.

Shirasaki F, Makhluf HA, LeRoy C, Watson DK \& Trojanowska M 1999 Ets transcription factors cooperate with Spl to activate the human tenascin-C promoter. Oncogene $187755-7764$.

Sun Y \& Duckworth ML 1999 Identification of a placental-specific enhancer in the rat placental lactogen II gene that contains 
binding sites for members of the Ets and AP-1 (activator protein 1) families of transcription factors. Molecular Endocrinology 13 385-399.

Tabanelli S, Tang B \& Gurpide E 1992 In vitro decidualization of human endometrial stromal cells. Fournal of Steroid Biochemistry and Molecular Biology 42 337-344.

Takai N, Miyazaki T, Fujisawa K, Nasu K \& Miyakawa I 2000 Expression of c-Ets1 is associated with malignant potential in endometrial carcinoma. Cancer 89 2059-2067.

Trojanowska M 2000 Ets factors and regulation of the extracellular matrix. Oncogene $196464-6471$.

Wasylyk B, Wasylyk C, Flores P, Begue A, Leprince D \& Stehelin D 1990 The c-ets proto-oncogenes encode transcription factors that cooperate with c-Fos and c-Jun for transcriptional activation. Nature 346 191-193.

Watanabe K, Kessler CA, Bachurski CJ, Kanda Y, Richardson BD, Stanek J, Handwerger S \& Brar AK 2001 Identification of a decidua-specific enhancer on the human prolactin gene with two critical activator protein 1 (AP-1) binding sites. Molecular Endocrinology 15 638-653.

Watson DK, McWilliams MJ, Lapis P, Lautenberger JA, Schweinfest CW \& Papas TS 1988 Mammalian ets-1 and ets-2 genes encode highly conserved proteins. PNAS $857862-7866$.

Woods DB, Ghysdael J \& Owen MJ 1992 Identification of nucleotide preferences in DNA sequences recognised specifically by c-Ets-1 protein. Nucleic Acids Research 20 699-704.

Yang BS, Hauser CA, Henkel G, Colman MS, Van Beveren C, Stacey KJ, Hume DA, Maki RA \& Ostrowski MC 1996 Ras-mediated phosphorylation of a conserved threonine residue enhances the transactivation activities of c-Ets-1 and c-Ets-2. Molecular and Cellular Biology 16 538-547.

Received in final form 28 March 2002 Accepted 15 April 2002 